\title{
Effectiveness of participatory-action-research to put in practice evidence at a nursing onco-hematology unit ${ }^{1}$
}

\author{
Eva Abad-Corpa ${ }^{2}$ \\ Julio Cabrero-García ${ }^{3}$ \\ Pilar Delgado-Hito ${ }^{4}$ \\ Andrés Carrillo-Alcaraz ${ }^{5}$ \\ Cristobal Meseguer-Liza ${ }^{6}$ \\ José Tomás Martínez-Corbalán
}

The aim was to evaluate the effectiveness of evidence implementation through participatoryaction research (PAR). A prospective quasi-experimental design with two non-equivalent and non-concurrent groups (2006 and 2008) was adopted. The research was conducted at the bone marrow transplant unit of a tertiary-level Spanish hospital. To put the evidence in practice, PAR was adopted as an "intervention studied". The dependent variables were: professional performance and patient outcomes (psycho-emotional area and adverse effects). In total, 125 patients were recruited $\left(1^{\text {st }}\right.$ period $=56 ; 2^{\text {nd }}$ period $=69$ ). The results in the second period show significant improvements in professional performance in terms of the quality of the registers of signs and symptoms. In the psycho-emotional area, the psycho-social adjustment improved significantly; without caregiver burden or satisfaction showing any clear tendencies. Among the adverse effects, catheter-related thrombosis and catheter-related infection improved significantly; there were no significant differences in the level of pain or mucositis. Through the PAR, evidence could be put in practice and the outcomes under analysis could be improved.

Descriptors: Evidence-Based Nursing; Comparative Effectiveness Research; Oncologic Nursing; Hematologic Diseases.

\footnotetext{
${ }^{1}$ Paper extracted from project "Análisis de la efectividad de la implantación de un modelo de Enfermería Basada en la Evidencia, mediante una investigación-acción-participante, en una unidad de oncohematología". Supoorted by Fondo de Investigación Sanitaria (PI051330).

2 RN, M.Sc. in Nursing Science, Technical Training and Research, Consejería de Sanidad, Murcia, Spain. Head of Strategic Planning Area of Nursing and Healthcare Research Unit (Investén-isciii), Spain. E-mail: eva.abad@carm.es; evaabadcorpa@ono.com.

3 Doctor of Psychology, Full Professor, Facultad de Enfermería, Universidad de Alicante, Spain. E-mail: julio.cabrero@ua.es.

${ }^{4}$ RN, Ph.D. in Nursing Science, Associate Professor, Facultad de Enfermería, Universidad de Barcelona, Spain. E-mail: pdelgado@ub.edu.

${ }^{5}$ Physician, Hospital General Universitario J. Ma Morales Meseguer, Murcia, Spain. E-mail: 968246333@telefonica.net.

${ }^{6}$ RN, Ph.D. in Pedagogy, Professor, Escuela de Enfermería, Universidad de Murcia, Spain. E-mail: crmeli@ono.com.

${ }^{7}$ RN, Hospital General Universitario, Murcia, Spain. E-mail: josetomasmc@gmail.com.
} 


\title{
Avaliação da efetividade da aplicação de evidências por meio de pesquisa-ação-participante em uma unidade de enfermagem hematológica
}

O objetivo deste estudo foi avaliar a efetividade da aplicação de evidências pela pesquisa-ação-participante (PAR). Como método usou-se o desenho quase-experimental prospectivo, com dois grupos não equivalentes e concorrentes (2006-2008), em uma unidade de enfermagem para transplante de medula óssea de hospital terciário espanhol. A intervenção estudada foi a integração de evidências pela PAR. As variáveis dependentes estudadas foram: o desempenho profissional e os resultados de saúde nos pacientes (área psicoemocional e efeitos adversos). Recrutaram-se 125 pacientes (Grupo 1=56, Grupo 2=69). Pôde-se observar pelos resultados melhora significativa no segundo grupo, na qualidade dos registros de enfermagem na avaliação de sinais e sintomas do paciente. Na área psicoemocional, o ajuste psicossocial do paciente melhorou significativamente, porém, nenhuma mudança foi observada na sobrecarga do cuidador ou satisfação do paciente. Em relação aos efeitos adversos, tanto o bloqueio quanto a infecção relacionada ao cateter melhoraram significativamente, mas não foi encontrada nenhuma diferença na dor nem na mucosite. Conclui-se que a PAR tem servido para apresentar evidências e melhorar os resultados de saúde.

Descritores: Enfermagem Baseada em Evidências; Pesquisa Comparativa de Efetividade; Enfermagem Oncológica; Doenças Hematológicas.

\section{Evaluación de la efectividad de la implantación de evidencias mediante una investigación-acción-participante en una unidad de enfermería oncohematológica}

\begin{abstract}
La finalidad fue evaluar la efectividad de la implantación de evidencias mediante una investigación-acción-participante (IAP). Diseño cuasi-experimental prospectivo con dos grupos no equivalentes ni concurrentes (2006 a 2008) en una unidad de enfermería de trasplante de medula ósea de un hospital español de tercer nivel. La intervención estudiada fue la implantación de evidencias mediante una IAP. Las variables dependientes: desempeño profesional y resultados de salud (área psico-emocional y efectos adversos). Se reclutaron 125 pacientes $\left(1^{\mathrm{er}}\right.$ grupo $=56 ; 2^{\circ}$ grupo=69). Se aprecia una mejoría significativa en el segundo grupo en la calidad de los registros de valoración de signos y síntomas. En el área psico-emocional, el ajuste psico-social mejora significativamente; no hay cambios en la sobrecarga ni la satisfacción. En efectos adversos, la obstrucción e infección relacionada con catéter mejoran significativamente; no hay diferencias en dolor y mucositis. La IAP ha servido para implantar evidencias y mejorar los resultados de salud.
\end{abstract}

Descriptores: Enfermería Basada en la Evidencia; Investigación sobre la Eficacia Comparativa; Enfermería Oncológica; Enfermedades Hematológicas.

\section{Introduction}

In the health area, compiling evidence is mandatory, given the enormous amount of knowledge production that is neither applied nor used(1).
Staying perfectly up-to-date, however, is a huge task for clinicians if they try to do this in isolation. Current trends are much more realistic and tend to 
consider "creators" and "users" of evidence the former have already digested, summarized and evaluated(2-3).

In health, Evidence-Based Practice (EBP) has turned into an international trend, which will play a key role to improve health organizations ${ }^{(4)}$. Using EBP is not exclusively achieved through increased knowledge, but demands a change in attitudes and conducts ${ }^{(5-6)}$.

Although the initial proposal of this new health care philosophy dates back more than 15 years(7), we need to continue investigating the effectiveness of its use and the mechanisms needed to put it in practice. Extensive literature exists about recommendations for the implementation of evidence in practice and the assessment of different interventions ${ }^{(8-10)}$.

To actually and effectively achieve the implementation of evidence in the complex reality of clinical practice (CP), we need to understand the mechanisms that motivate changes in the organization and its teams. The necessary research should involve professionals and researchers as a whole, through an action process that needs to involve experience and reflection to be able to improve or change practices. This type of research is called "participatory-actionresearch" (PAR)(11) and has already been used as a means to implement evidence in $\mathrm{CP}^{(12)}$, considering the participants' viewpoint. A review elaborated in 2009 found 21 papers that attempted to put in practice evidence through action-research ${ }^{(13)}$, positively assessing its effects on knowledge, professional performance, the structural context and patient outcomes. This review ${ }^{(13)}$ insisted that patient outcomes were the least explored in PAR literature.

In this paper, we show the assessment results of a global project(14) to put in practice evidence at an onco-hematology unit of a Spanish hospital. Therefore, the following were proposed as the general aim - To assess the effectiveness of evidence implementation in $\mathrm{CP}$ through a PAR, in terms of professional performance and patient health outcomes; and as specific aims - To analyze differences in the assessment and control of signs and symptoms in both patient groups: pain, risk of pressure ulcer (PU), mucositis, nutritional status, nausea and vomiting; To analyze differences in the psycho-emotional area in both patient groups: anxiety, caregiver burden, adjustment of psychosocial impact and satisfaction with care; To analyze differences in adverse effects in both patient groups: venous catheterrelated infection, venous catheter obstruction, PU, mucositis and pain level.

\section{Methods}

Design: A quasi-experimental, prospective design was used, with two non-equivalent and non-concurrent groups.

Study context: The study was developed at the isolation unit for onco-hematology patients of a tertiary-level public teaching hospital in Spain. This unit comprises eight beds for onco-hematology patients, with a mean stay of one month at the unit. The nurse/ patient ratio is $1: 3$.

Study period: Data for the first patient group were collected in 2006. The intervention (evidence implementation through a PAR) took nine months in 2007, followed by a maturation period of the changes in CP. The second quantitative patient data collection phase took place in 2008.

Study participants: The eligible population included patients hospitalized at the unit, submitted to bone marrow transplantation or neutropenic patients who needed isolation or initial/relapse leukemia patients who needed hospitalization during the study period and complied with the following inclusion criteria: age $>18$ years, stay at the unit $>3$ days, intact cognitive skills and patients who signed the informed consent form. Deteriorated cognitive skills and participation in another clinical research were established as exclusion criteria.

Given that it was unknown how such a complex intervention would behave, with a very large number of dependent variables, that the estimated hospitalization rate was estimated at 70 patients for every time series and that the research team was able to include all hospitalized patients, the sample size was not calculated.

Data collection: The study variables were assessed across the patients' hospital stay, using the records in the clinical history of hospitalization, either through the researchers' direct evaluation and/or with the help of self-administered instruments (depending on the variable under analysis). To better capture the phenomenon, and depending on the nature of the variables, some were valued when the effects of chemotherapy and radiotherapy were at a height (severe neutropenia with minimum level of "absolute neutrophil count" $(\mathrm{ANC}<500))$. For other variables, the measurement moment was set when improvement was visible (ANC>500). The following variables were collected in both patient groups: 
1. Clinical and socio-demographic variables: Age, gender, medical diagnosis, days of stay, mortality, pharmacological treatments, albumin level and venous catheterization characteristics.

2. Professional performance (sign and symptom control): - PU risk: the quality of records related to the evaluation of PU risk through the EMINA scale was evaluated before and after the intervention ${ }^{(15)}$;

- Mucositis evaluation: Pre- and post-intervention records were analyzed about the evaluation of the mucositis level, using the World Health Organization's (WHO) mucositis scale ${ }^{(16)}$;

- Nausea and vomiting: Pre- and post-intervention records were analyzed about the evaluation of nausea and vomiting.

- Pain assessment: Measured on the second day of ANC $>500$ through a Visual Analogue Scale (graded from 0 to $10 \mathrm{~cm}$ ), asking the patient to globally indicate how (s)he would score the nursing staff's pain control. Similarly, pre and post-intervention records were analyzed about pain assessment.

- Nutritional assessment: The number of interconsultations to the Nutrition Unit was analyzed before and after the intervention.

3. Patient health outcomes:

3.1 Psycho-emotional area

- Impact of psychosocial factors associated with hospitalization: Measured on the fourth day of ANC $<500$ and upon discharge from the unit, using the Psychosocial Adjustment to Illness Scale (PAIS) ${ }^{(17)}$.

- Anxiety: Trait anxiety was measured upon hospitalization, using the Spanish version of the STAI questionnaire(18); state anxiety was measured on the fourth day of ANC $<500$ and upon discharge.

- Caregiver burden: Measured on the fourth day of ANC $<500$ and upon discharge from the unit, through the Spanish version of the Zarit caregiver burden Scale(19) (on average, this type of patient is hospitalized for one month together with a caregiver).
- Satisfaction with nursing care: Measured on the fourth day of $A N C<500$ and upon discharge from the unit, using the Spanish short version of the La Monica-Oberst Patient Satisfaction (LOPSS12)(20).

3.2 Adverse effects:

- Pain level: Measured on the second day of ANC>500 through a Visual Analogue Scale (graded from 0 to 10 $\mathrm{cm})$, asking the patient to globally indicate the pain suffered at the unit.

- Mucositis level: The maximum level of mucositis reached during hospitalized was collected through the WHO scale (graded from 0 to 4$)^{(16)}$.

- Pressure ulcer: The incidence of PU was analyzed.

- Venous catheter related infection: The accumulated incidence of pericatheter infection, catheter-related bacteremia (CRB) and catheter colonization was analyzed in relation to the total number of catheters and total catheters-day.

- Venous catheter obstruction: The accumulated incidence of obstruction was analyzed in relation to the total number of catheters and total catheters-day.

Intervention under analysis: The intervention under analysis was a PAR ${ }^{(21)}$; the implemented evidence, whose effectiveness had already been demonstrated in $\mathrm{CP}^{(22-24)}$, is listed next and the entire process is schematically represented in Picture 1: a) Use of chlorhexidine as an antiseptic in central venous catheter handling and protocol update; b) Evaluation of nausea, mucositis, risk of pressure ulcer and pain, using validated instruments; c) Expert assessment of malnutrition risk; d) Music therapy administration; e) Use of cryotherapy together with the cytostatic agent 5-fluorouracil; f) Incorporation of patient preferences in decision making; g) Incorporation of help relation in patient care.

Data analysis: SPSS 15.0 statistical software was used for data analysis.

Descriptive: Descriptive analysis of both groups and calculation of central trend and dispersion measures according to each variable's distribution. 


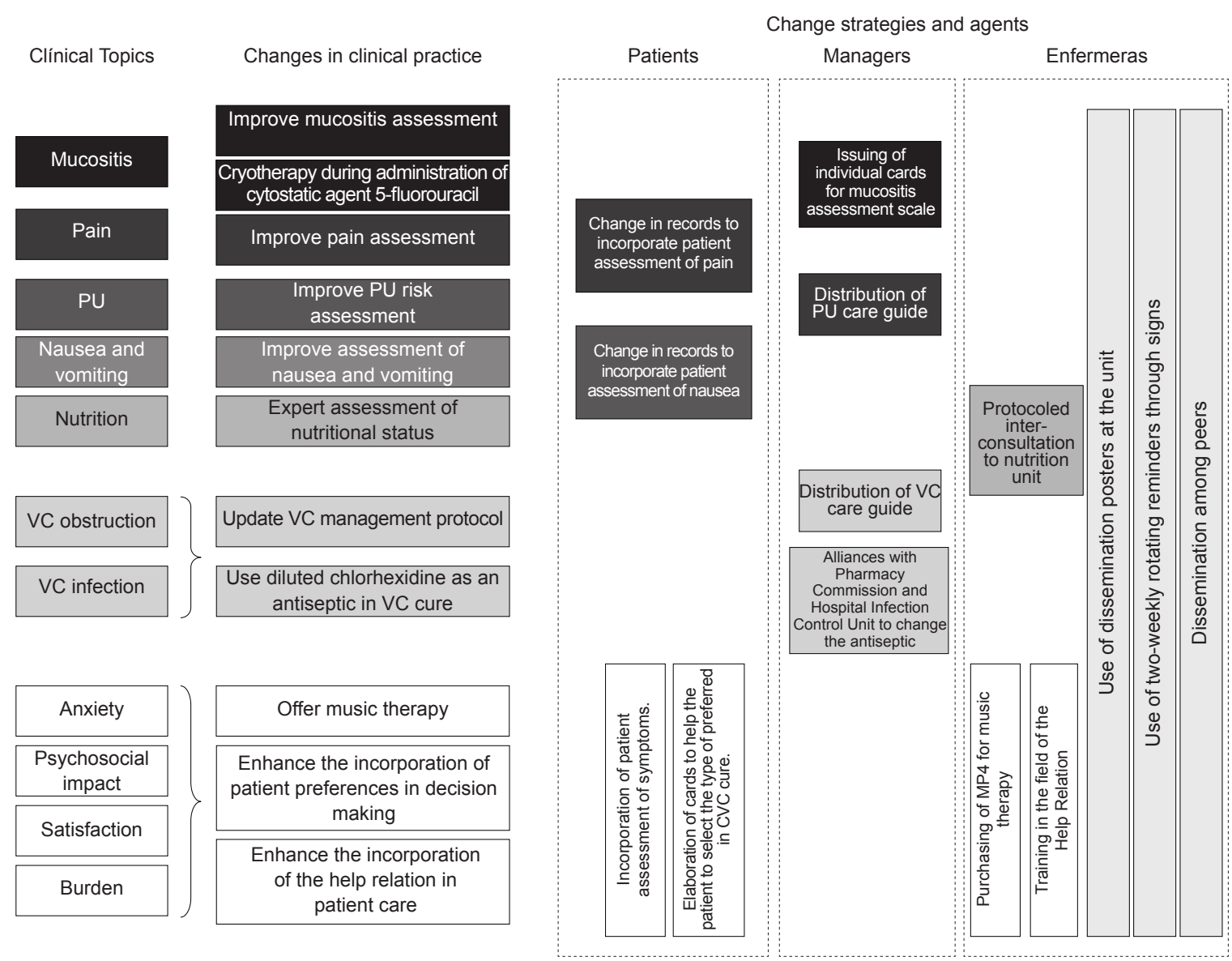

Figure 1 - Relation among clinical topics studied, changes, strategies and agents

Comparison between professional performance and patient health outcome variables in patients from each group: For the psychosocial adjustment, venous catheter-related infection and obstruction variables, effectiveness was analyzed and effect measures were calculated (absolute risk reduction with 95\% confidence intervals): also, for the survival of the venous catheters, the Kaplan-Meier method was used; finally, for those variables with different measures along the hospital stay, intra-group changes were analyzed.

Quantitative variables: to compare means, Student's t-test or Mann-Whitney was used (depending on normal distribution or not) and ANOVA and KruskalWallis. To compare means, the Wilcoxon and KruskalWallis tests were used.

Qualitative variables: to compare these variables, chi-square and Fisher's exact test were used.

Ethical considerations: Approval for the project was obtained from the hospital's Clinical Research Ethics Committee and all participants took part voluntarily, after signing an Informed Consent Form. They were free to drop out of the study at any time and the confidentiality of their personal and family data was guaranteed.

\section{Results}

In total, 125 patients were included in both collection periods. In the pre-intervention group, 56 patients were recruited. Different losses occurred in the estimated patient inclusion: four patients were under age, six refused to participate, two dropped out and 12 patients were unexpectedly included in a commercial clinical trial. In the post-intervention group, 69 patients were included, while 11 could not be recruited: 1 patient refused to participate, data were lost for 2 patients and 8 dropped out.

Out of the 27 control variables studied, differences were found in 6 of them (medical diagnosis, neutropenia, days post-transplantation, immunosuppresive treatment, corticoids, opioids); despite these differences, we considered the groups were similar in terms of fundamental clinical variables.

The results concerning intervention effectiveness (Tables 1, 2 and 3 ) reveal that the introduction of evidence in CP through a PAR can strongly improve the results under analysis.

Professional performance: After the intervention, the quality of $\mathrm{PU}$ risk, pain and nausea and vomiting records clearly improved (Table 1 ). Patients' opinion regarding the evaluation of pain management by nursing 
did not change though ( $8.3 \pm 1.9$ vs. $8.5 \pm 2.1 ; \mathrm{p}: .426)$. Similarly, in the second group, nutritional assessment improved, although not significantly (Table 1 ). The unit protocol indicated that, in the pre-intervention group, inter-consultations to the Nutrition unit should have taken place for at least 25 risk patients (according to the EMINA scale), but this was the case for only 10 patients (40\%). On the opposite, in the post-intervention group, this happened for all identified risk patients.

Table 1 - Comparison of sign and symptom control

\begin{tabular}{lccc}
\hline & $\begin{array}{c}\text { Pre- } \\
\text { intervention } \\
\mathbf{n = 5 6}\end{array}$ & $\begin{array}{c}\text { Post- } \\
\text { intervention } \\
\mathbf{n = 6 9}\end{array}$ & p-value $^{\dagger}$ \\
\hline Days without PU records & $23.3 \pm 23.1^{*}$ & $8.6 \pm 10.5^{*}$ & $<.001$ \\
Pain records per patient & 0 & $42.1 \pm 32.6^{*}$ & $<.001$ \\
Nausea records per patient & 0 & $40.3 \pm 30.6^{*}$ & $<.001$ \\
Mucositis records per patient & $0.1 \pm 0.4^{*}$ & $12.4 \pm 12.2^{*}$ & $<.001$ \\
Inter-consultation to Nutrition & $10(17.9 \%)$ & $15(22.4 \%)$ & 0.534 \\
Unit & & & \\
\hline
\end{tabular}

*Mean \pm Standard Deviation

${ }^{+}$Statistical significance, $\mathrm{p}$-value $<0.05$
Health outcomes in the psycho-emotional area: The post-intervention group displays significant improvement in the psychosocial impact along the hospitalization period ( $2.1 \pm 2.4$ vs. $1.1 \pm 2.3 ; \mathrm{p}:<.001)$, with an absolute risk reduction by 1 ( $95 \%$ CI $0.13-1.87$ ). Although the caregiver burden is higher in the post-

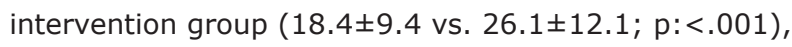
it drops during the hospital stay, while it increases in the pre-intervention group (18.6 \pm 10.4 vs. $23.3 \pm 12.1$; $\mathrm{p}: .085)$, with better results for the post-intervention group ( $4.5 \pm 3.8$ vs. $6.5 \pm 5.6 ; \mathrm{p}: .045)$.

No statistically significant differences were found either in satisfaction with nursing care upon discharge (56.4 \pm 14.4 vs. $58.4 \pm 13.1 ;$ p: .522). The number of satisfied patients along the hospitalization period increases more in the post-intervention group though (Figure 2).

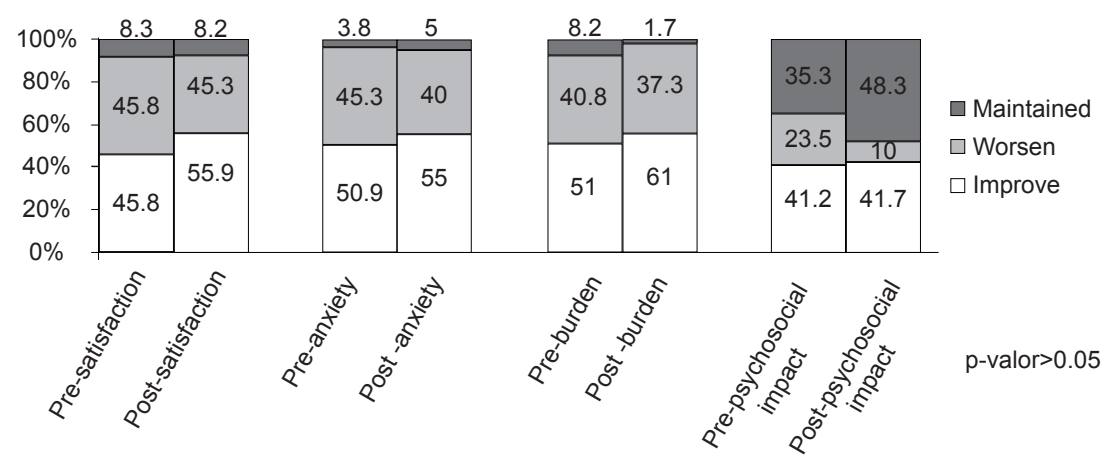

Figure 2 - Evolution in psychosocial variables during hospitalization

Anxiety data reveal a post-intervention group with

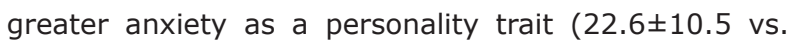
$26.3 \pm 9.1 ; p: .038)$. This probably influences the fact that, in that group, when $\mathrm{ANC}<500$ and upon discharge, state anxiety levels are higher; the analysis of how this variable evolves along the hospitalization period, however, reveals clearer improvements in this group after the intervention ( $9.7 \pm 9.1$ vs. $12.6 \pm 7.1 ; \mathrm{p}: .083$ ).

Regarding intra-group changes, the analysis of psycho-emotional variables measured on different occasions reveals a significant improvement in caregiver burden in the intervention group (Table 2).

Table 2 - Differences between scores measured upon discharge and during the first assessment in the psychoemotional area

\begin{tabular}{|c|c|c|c|c|}
\hline & & $\begin{array}{c}\text { Pre-intervention } \\
n=56\end{array}$ & $\begin{array}{c}\text { Post-intervention } \\
n=69\end{array}$ & p-value ${ }^{\dagger}$ \\
\hline \multirow[t]{2}{*}{ Anxiety } & Score change ${ }^{\ddagger}$ among patients who get better & $9.7 \pm 9.1^{*}$ & $12.6 \pm 7.1^{*}$ & .083 \\
\hline & Score change ${ }^{\ddagger}$ among patients who get worse & $6.5 \pm 4.5^{*}$ & $6.3 \pm 4.6^{*}$ & .694 \\
\hline \multirow[t]{2}{*}{ Psychosocial impact } & Score change ${ }^{\ddagger}$ among patients who get better & $3.5 \pm 2.5^{*}$ & $3.4 \pm 2.2^{*}$ & .867 \\
\hline & Score change ${ }^{\ddagger}$ among patients who get worse & $2.7 \pm 2.1^{*}$ & $3.5 \pm 2.5^{*}$ & .494 \\
\hline \multirow[t]{2}{*}{ Satisfaction } & Score change ${ }^{\ddagger}$ among patients who get better & $12.3 \pm 13.3^{*}$ & $10.7 \pm 11.8^{*}$ & .730 \\
\hline & Score change ${ }^{\ddagger}$ among patients who get worse & $8.3 \pm 11.9^{*}$ & $6.6 \pm 6.4^{*}$ & .961 \\
\hline \multirow[t]{2}{*}{ Caregiver burden } & Score change ${ }^{\ddagger}$ among patients who get better & $4.5 \pm 3.8^{*}$ & $6.5 \pm 5.6^{*}$ & .045 \\
\hline & Score change $e^{\ddagger}$ among patients who get worse & $6.6 \pm 4.6^{*}$ & $5.4 \pm 4.4^{*}$ & .310 \\
\hline
\end{tabular}

$*$ Mean \pm Standard Deviation ${ }^{+}$Statistical significance, $\mathrm{p}$-value $<0.05$ * Score change between discharge and first measurement 
Health outcomes for adverse effects: Each patient used various venous catheters and venous catheter characteristics (Table 3) show that both groups were comparable, despite more catheterization days for central venous catheters (CVC) and less for peripheral ones.

Although most patients in the post-intervention group used a CVC (accompanied by greater infection risk), figures for this type of nosocomial infection (table 3) show statistically significant results in favor of that group (pericatheter infection, CRB and catheter colonization). If we group these three variables in a joint result, the absolute risk reduction amounted to $19.6 \%$ (95\% CI 7.4-31.7; p: .001) for the post-intervention group.

Table 3 - Venous catheterization characteristics of patients and outcomes concerning venous catheter-related infection

\begin{tabular}{|c|c|c|c|c|}
\hline & & $\begin{array}{c}\text { Pre-intervention } \\
\mathrm{n}_{\text {cat. }}=72\end{array}$ & $\begin{array}{c}\text { Post-intervention } \\
n_{\text {cat. }}=87\end{array}$ & $p$-value ${ }^{\dagger}$ \\
\hline CVC & & $55(76.4 \%)$ & $76(87.4 \%)$ & .071 \\
\hline \multirow[t]{2}{*}{ CVC Type } & Conventional & $54(75.0 \%)$ & $83(95.4 \%)$ & $<.001$ \\
\hline & Indwelling & $18(25.0 \%)$ & $4(4.6 \%)$ & \\
\hline \multirow[t]{5}{*}{ Location } & Jugular & $47(65.3 \%)$ & $54(62.1 \%)$ & .533 \\
\hline & Subclavian & $5(6.9 \%)$ & $7(8.0 \%)$ & \\
\hline & Peripheral CVC & $3(4.2 \%)$ & $10(11.5 \%)$ & \\
\hline & Femoral & $1(1.4 \%)$ & $2(2.4 \%)$ & \\
\hline & Others & $16(22.2 \%)$ & $14(16.1 \%)$ & \\
\hline \multirow[t]{3}{*}{ Catheter duration (days) } & Catheter & $22.0 \pm 13.3^{*}$ & $20.8 \pm 16.1^{*}$ & .602 \\
\hline & CVC & $27.1 \pm 10.9^{*}$ & $22.4 \pm 16.5^{*}$ & .002 \\
\hline & Peripheral & $5.5 \pm 2.4^{*}$ & $9.2 \pm 4.8^{*}$ & .003 \\
\hline \multirow[t]{3}{*}{ Infection } & Pericatheter infection & $13(18.1 \%)$ & $4(4.6 \%)$ & .006 \\
\hline & Bacteremia & $5(6.9 \%)$ & $1(1.1 \%)$ & .136 \\
\hline & Catheter colonization & $8(11.1 \%)$ & $1(1.1 \%)$ & .012 \\
\hline \multirow[t]{3}{*}{ Infection per 1000 catheters/day } & Pericatheter infection & 8.2 & 2.2 & .025 \\
\hline & Bacteremia & 3.2 & 0.6 & .163 \\
\hline & Catheter colonization & 5.1 & 0.6 & .024 \\
\hline
\end{tabular}

*Mean \pm Standard Deviation ${ }^{+}$Statistical significance, $\mathrm{p}$-value $<0.05$ Central venous catheter (CVC)

Catheter obstruction results show considerable improvement in the post-intervention group, with statistically significant differences for the absolute reduction of obstruction risk (21.4\%; 95\% CI 6.4-36.5; p: .003), incidence density (No. of obstructions/1000 catheter days: 29 vs. 14.4; p: .005) and longer dwelling time of catheters without obstruction, although not

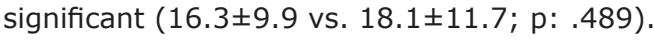

Finally, no significant differences were found in the pain level felt ( $3.1 \pm 2.8$ vs. $2.6 \pm 2.7 ; \mathrm{p}: .448)$, nor in the

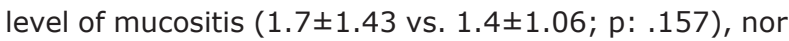
in PU incidence (1.8\% vs. $1.5 \% ; \mathrm{p}: 1.000)$.

\section{Discussion}

The project results reveal that the introduction of evidence in nursing practice through a PAR can improve certain health outcomes in onco-hematological patients, as well as the quality of their care processes.

Changes in CP represent highly complex problems, whose correct study demands different methodological perspectives $^{(25)}$; our research design achieved an integrative attitude towards the project, as reality comprises not only data, but also facts, successes, situations etc. ${ }^{(26)}$, which need to be taken into account to be able to successfully produce changes in CP.

Thus, in the post-intervention group, considerable improvement is found in the quality of sign and symptom assessment records (PU risk, pain, mucositis and nausea and vomiting), similar to other studies on the professional performance dimension ${ }^{(13)}$.

With regard to the psycho-emotional area, data do not reveal a clear trend, although important differences appear in some variables, such as the PAIS. The sensitivity of the instruments used to measure anxiety and caregiver burden may be low to detect changes. On the other hand, in our study, no change was found in patient satisfaction, as opposed to other studies that used PAR to put evidence in practice ${ }^{(13)}$. The instrument these authors used divides satisfaction into dimensions, obtaining significant differences for physical care and discharge planning; the instrument we used assesses satisfaction globally, and is less specific and more centered on the "affability" dimension. 
As for the results related to the appearance of adverse effects, data show great improvement in the post-intervention group for those results related to venous catheterization. No differences appear in other adverse effects like the level of mucositis or PU incidence. Improvement in the latter did appear in other studies that used PAR to put in practice evidence in PU care at home ${ }^{(13)}$; in our study, the range of improvements in this outcome was very narrow, given the low baseline incidence levels among the onco-hematological patients in our series.

Finally, we may say that the intervention analyzed (the PAR) has been very useful to introduce evidence in complex contexts like health. Thee Promoting Action on Research Implementation in Health Services Framework also acknowledges this social context as crucial for the implementation of research results in $\mathrm{CP}^{(27)}$, and more concretely in the nursing group ${ }^{(28)}$. Likewise, the fact of combining strategies that enhance change and multifaceted interventions has facilitated the success of the intervention ${ }^{(9,10)}$, as well as the fact that the leaders were members of the research team ${ }^{(29)}$. Moreover, as the stakeholders themselves produced the changes, this probably reduced resistance to change.

Despite the results obtained, possible study limitations should be taken into account: a) due to its non-randomized quasi-experimental design, sufficient control of confounding variables and other external and internal bias cannot be guaranteed; b) non-controlled researcher and patient expectations and their potential effects on outcome variables (as a control measures, the researchers responsible for statistical analysis did not know what group each patient belonged to); c) due to the qualitative nature of PAR, results cannot be generalized, but they can be extrapolated to similar situations or contexts; d) not all nurses at the unit may have carried out the change; e) possible problems in patient recruitment; f) some of the health outcomes studied are hardly sensitive to changes.

\section{Conclusions}

The implementation of evidence through a PAR process has improved many of the health outcomes studied and the quality (in terms of processes) of nursing care. Moreover, the PAR managed that the changes in $\mathrm{CP}$ were generated from the interior of the nursing group at the unit.

Future studies could use PAR to implement evidence in other contexts and analyze the maintenance of changes over time. Similarly, strategies should be explored that join the potential of PAR with more solid quantitative designs than used in this research.

\section{Acknowledgements}

We are grateful for the work of the nurses who participated in the participating action research, for their dedication, enthusiasm and persistence.

Acknowledgements also to Carmen Lourdes Zárate Riscal, Amor Caravaca Hernández and Antonio Paredes Sidrach de Cardona for their cooperation with data collection.

\section{References}

1. Glasziou $P$, Haynes $B$. The paths from research to improved health outcomes. ACP J Club. 2005;142(2):A810.

2. Alper BS, White DS, Ge B. Physicians answer more clinical questions and change clinical decisions more often with synthesized evidence: a randomized trial in primary care. Ann Fam Med. 2005;3(6):507-13.

3. Urra Medina E, Barría Pailaquilén RM. La revisión sistemática y su relación con la práctica basada en la evidencia en salud. Rev. Latino-Am. Enfermagem. 2010;18(4):824-31.

4. Kitson A. The State of the Art and Science of EvidenceBased Nursing in UK and Europe. Worldviews Evid Based Nurs. 2004;1(1):6-8.

5. Coomarasamy A, Khan KS. What is the evidence that postgraduate teaching in evidence based medicine changes anything? A systematic review. $\mathrm{Br}$ Med J. 2004;329(7473):17-21. [acesso 15 fev 2011]. Disponível em: http://www.ncbi.nlm.nih.gov/pubmed/15514348

6. Estabrooks CA, Rutakumwa W, O'Leary KA, ProfettoMcGrath J, Milner M, Levers MJ, et al. Sources of Practice Knowledge Among Nurses. Qual Health Res. 2005;15(4):460-76.

7. Sackett DL, Rosenberg WM, Muir Gray JA, Haynes RB, Richardson WS. Evidence based medicine: what it is and what it isn't. Br Med J. 1996;312(13):71-2.

8. Rycroft-Malone J, Harvey G, Seers K, Kitson A, McCormack B, Titchen A. An exploration or the factors that influence the implementation of evidence into practice. J Clin Nurs. 2004;13:913-24.

9. Grimshaw JM, Shirran L, Thomas R, Mowatt G, Fraser $C$, Bero $L$, et al. Changing provider behaviour: an overview of systematic reviews of interventions to promote implementation of research findings by healthcare professionals. In: Getting Research findings into practice. 2nd ed. London: BMJ; 2002. p. 29-67. 
10. Thompson D, Estabrooks CA, Scott-Findlay S, Moore $\mathrm{K}$, Wallin L. Interventions aimed at increasing research use in nursing: a systematic review. Implement Sci. 2007;2:15-31.

11. Hills M, Mullet J. Enhancing Nursing Health Promotion through Cooperative Inquiry. In: Transforming Health Promotion Practice. Concepts, Issues, and Applications. Philadelphia: F.A. Davis; 2002.

12. Delgado, P., Gastaldo, D. Avaliaçao participativa da assistência en enfermagem em uma unidade de cuidados intensivos na Espanha. Da reflexao à mudança nas práticas do cuidado. En: Bosi ML, Mercado FJ, editors. Avaliação qualitativa de programas de saúde. Petrópolis: Vozes; 2006. p. 281-312.

13. Munten G, Van den Bogaard J, Cox K, Garretsen H, Bongers I. Implementation of Evidence-Based Practice in Nursing Using Action Research: A Review. Worldv Evid Based Nurs. 2010;7(3):135-57.

14. Abad-Corpa E, Meseguer-Liza C, Martínez-Corbalan JT, Zárate-Riscal L, Caravaca-Hernández A, ParedesSidrach de Cardona $A$, et al. Effectiveness of the Implementation of an Evidence-Based Nursing Model using Participatory Action Research in Oncohematology: research protocol. J Adv Nurs. 2010;66(8):1845-51.

15. Fuentelsaz C. Validación de la escala EMINA: un instrumento de valoración de riesgo de desarrollar úlceras por presión en pacientes hospitalizados. Enferm Clin. 2001;11(3):97-103.

16. World Health Organization. Handbook for reporting results of cancer treatment. Geneva; 1979.

17. Latour J, Gutiérrez T, Reig A. Construcción y validación de un índice de ajuste psicosocial en cuidados intensivos sin entrevista del paciente. Med Clin (Barc). 1994;102: 291-3.

18. Spielberger $C D$, Gorsuch RL, Lushene RE. Cuestionario de Ansiedad Estado-Rasgo. Adaptación española. Manual. $4^{a}$ ed. Madrid: TEA, Publicaciones de Psicología Aplicada; 1984.

19. Zarit SH, Zarit JM. The memory and behavior problems checklist and the burden interview (Technical report). University Park (PA): Pennsylvania State University; 1987.

20. Cabrero J, Richart M, Reeig A. Validez de constructo de tres escalas de satisfacción del paciente mediante la estrategia de matrices multirrasgo-multimétodo. Análisis Modificación de Conducta. 1995;21(77):359-95.

21. Abad-Corpa E, Delgado-Hito P, Cabrero-García J, Meseguer-Liza C, Zárate-Riscal L, Carrillo-Alcaraz A. Implementing evidence in nursing practice: a process of change using Participatory Action Research. (In Press).
22. Solano-Antolinos J, S Sánchez-Sánchez, E Abad-Corpa, JM Estrada-Lorenzo and JT MartínezCorbalán. 2008. Recuperando evidencias en pacientes oncohematológicos ( $1^{\text {a }}$ Parte): Mucositis, dolor y satisfacción (Finding evidence about oncohematological patients (1st Part): Mucositis, Pain and Satisfaction). NURE Investigación [perioidico na Internet]; 5 (37): [aprox 10 pant]. [acesso 16 mar 2010]; Disponível em: http://www.fuden.es/originales_detalle.cfm?ID_ ORIGINAL=112\&ID_ORIGINAL_INI =1

23. Sánchez-Martínez RC, A Carillo-Alcaraz, A CastañosOrtells, A Caravaca-Hernández, E Abad-Corpa and JM Estrada-Lorenzo. 2009. Recuperando evidencias en pacientes oncohematológicos ( $2^{a}$ Parte): Infección por catéter venoso y úlceras por presión (Finding evidence about oncohematological patients (2nd Part): Catheter-Related Infection and Pressure Ulcers). NURE Investigación [periodico na Internet]; 6 (39): [approx. 10 pant]. [acesso 16 mar 2010]; Disponível em: http://www.fuden.es/FICHEROS_ADMINISTRADOR/ ORIGINAL/recevicatulc_39.pdf

24. Lorenzo-García N, MD Sánchez-Ayala, C MeseguerLiza, JM Estrada-Lorenzo, L Zarate-Riscal, A ParedesSidrach de Cardona and E Abad-Corpa. 2009. Recuperando evidencias en pacientes oncohematológicos (30 parte): Valoración nutricional, nauseas y vómitos (Finding evidences on oncohematological patientes (3rd Part): Nutrition Assessment, Nauseas and Vomiting). NURE Investigación [Journal on Internet]; 6 (41): [aprox 9 pant]. [acesso 16 mar 2010]; Disponível em: http://www.fuden.es/FICHEROS_ADMINISTRADOR/ ORIGINAL/origevidonctres41106200914248.pdf.

25. Tashakkori A, Teddlie C. Handbook of mixed method in social and behavioural research. Thousand Oaks: Sage; 2003.

26. Furegato ARF. Reflexión acerca del dualismo metodológico en las investigaciones en salud. Rev. Latino-Am. Enfermagem. 2008;16(6):941-2.

27. Rycroft-Malone J, Seers K, Titchen A, Harvey G, Kitson A, McCormack B. What counts as evidence in evidencebased practice?. J Adv Nurs. 2004;47(1):81-90.

28. Kortteisto T, Kaila M, Komulainen J, Mantyranta T, Rissanen P. Healthcare professionals' intentions to use clinical guidelines: a survey using the theory of planned behaviour. Implement Sci. 2010;5(1):51.

29. McCormack B, Kitson A, Harvey G, Rycroft-Malone J, Titchen A, Seers K. Getting evidence into practice: The meaning of context. J Adv Nurs. 2002;38(1):94-104.

Received: Fev. $14^{\text {th }} 2011$ Accepted: Jan. $6^{\text {th }} 2012$ 